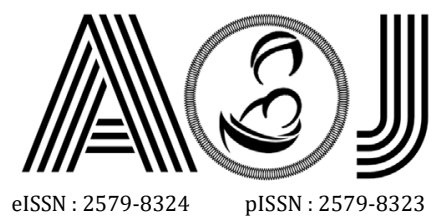

\title{
RESEARCH
}

\section{Effect of Virgin Coconut Oil in The Treatment of Leucorrhea Caused by Candida Albicans Infection on Pregnant Women at Hospitals in Padang}

Putri Zelfitri Zen ${ }^{1}$, Desmiwarti ${ }^{2}$, Sumaryati Syukur ${ }^{3}$

Affiliation author: 1. Obstetrics and Gynecology Department, Faculty of Medicine, Andalas University, Dr. M. Djamil Central General Hospital Padang, West Sumatera, Indonesia; 2. Sub Division of Social Obstetrics and Gynecology, Obstetrics and Gynecology Department, Faculty of Medicine, Andalas University, Dr. M. Djamil Central General Hospital Padang, West Sumatera, Indonesia; 3. Study program of Chemistry, Faculty of Mathematics and Natural Sciences, Andalas University, Padang, West Sumatera, Indonesia

Correspondence to: Putri Zelfitri Zen, email: zelfie.de.junand@gmail.com, Hp: 085271129393

\section{Abstract}

Introduction : According to WHO, the prevalence of reproductive health problems in women has reached 33\% from all types of diseases. One of the most frequent reproductive health problems is fluor albus. The incidence of candidiasis in pregnant women has doubly increased, especially at third trimester, compared to women who were not pregnant. Candida should be considered a dangerous pathogen in early pregnancy.

Objective : This study compared the number of colonies before and after the administration of virgin coconut oil (VCO) to address vaginal discharge caused by C. albicans infection in pregnant women.

Material and methods: This is an experimental study on 36 pregnant women. Examination of fluor albus is done by applying vaginal swab before and after administration of 1 tablespoon of VCO orally three times a day dan 5cc of VCO was applied on the vagina and vulva for intervention group, meanwhile the control group was not given anything. Statistical analysis to test the significance is done by using T-test.

Results : There was a difference on average number of colonies with higher number of colonies prior to administration $(137.17 \pm 16.35 \mathrm{vs} 122.17 \pm 14.42)$. The average number of colonies at the first examination was $96.06 \pm 8.85$ colonies and increased at the second examination to $112.89 \pm 12.49$ colonies.

Conclusion : There was an effect of VCO administration on decreasing the number of colonies in the intervention group $(p=0.000)$, while in control group, there was increasing average number of colonies in the second examination $(p=0.000)$.

Keywords: Candida albicans, fluor albus, pregnant women, virgin coconut oil

\section{BACKGROUNDS}

According to WHO, the prevalence of reproductive health problem in women has reached $33 \%$ of all types of diseases. One of the most common reproductive health problems in women is white discharge/leucorrhea/fluor albus. ${ }^{1}$ One of the etiologies of leucorrhea is Candida albicans. Globally, there is an increasing number of leucorrhea caused by Candida 


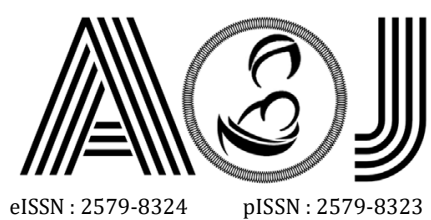

eISSN : 2579-8324
pISSN : 2579-8323

albicans or well known as vaginal candidiasis. Vaginal candidiasis infects vaginal and/or vulva mucosal area. ${ }^{2,3}$ In Indonesia, around $75 \%$ of women experienced leucorrhea at least once in their life, and another $45 \%$ of them experienced leucorrhea two or more times in their life. According to a study conducted by Wiknjosastro in $2008,42.9 \%$ of women with leucorrhea are pregnant women, and the incidence of candidiasis is almost doubled in pregnant women especially in the third trimester than in women who are not pregnant. ${ }^{1}$ In Nepal, a study conducted by Khushbu Yadav in 2016 about the prevalence of vulvovaginal candidiasis in pregnancy showed that the incidence of candidiasis in pregnant women has doubly increased, especially at age of 20-25 in the second trimester. ${ }^{1,4}$

Vaginal candidiasis is one of reproductive tract infection disease that frequently occur at pregnancy. ${ }^{2,3}$ It is believed that higher estrogen and progesterone levels in vaginal secretion during pregnancy increase a women's risk of developing vaginal candidiasis. Estrogen has the ability to reduce vaginal epithelial cells to slower C. albicans' growth. Besides, estrogen also decreases immunoglobulins in vaginal secretions. ${ }^{5,6,7}$ Candida should be considered as a dangerous pathogen in early pregnancy as its capability to cause serious morbidity in pregnancy, such as risk of spontaneous abortion, chorioamnionitis, preterm delivery, and immune system weakening. ${ }^{8,9}$

Various medication regimens used for approximately 3 days can be used to address leucorrhea, but the increase in antibiotics and antifungal usage possibly contribute to a high incidence of adverse effect and drug resistance. One of the factors of the change in $\mathrm{C}$. albicans infection epidemiology is decreasing in sensitivity of $\mathrm{C}$. albicans towards antifungal agents. According to a study conducted by Sanguinetti and Posteraro in 2015, they found that fluconazole which has been used widely as antifungal now resistant to $C$. albicans. The study also showed that fluconazole administration in pregnancy increases the risk for congenital anomalies, such as craniosynostosis, cleft lip, limb reduction defect, polydactyly, and syndactyly. Another study by Salehei et al in 2012 showed that 43 C. albicans isolated from vaginal sample showed resistance towards fluconazole and econazole as its antifungal. The same result was also shown by other earlier studies in 2006 by Cernika and Subik which found that among 22 resistant $C$. albicans isolate, 12 showed resistance towards itraconazole and another 15 towards voriconazole. ${ }^{10,11,12}$ The management of Candida albicans in pregnancy is much more difficult because of weakening of clinical response and frequent incidence of recurrency. Administration of topical antifungal is effective enough if it is used for long-term ( $1-2$ weeks), however this antifungal also carries negative impact towards the fetus, such as renal impairment. ${ }^{13,14}$

Recent study showed that virgin coconut oil (VCO) is natural based medicine that is effective at controlling Candida albicans infection. ${ }^{13,14}$ Virgin coconut oil contains fatty acids that attribute as antifungal. Fatty acid contained in VCO works directly at fungal membrane 


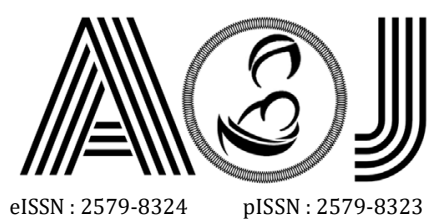

eISSN : 2579-8324
pISSN : 2579-8323

to prevent resistance and shorten the yeast life age. ${ }^{15-18}$ The aim of this study is to determine the effect of administration of VCO in the management of leucorrhea which is caused by Candida albicans in pregnant women at network hospitals in Padang.

\section{MATERIALS AND METHOD}

This study is conducted on pregnant women who came with complain of vaginal itching, irritation, and thick milky white discharge to some hospitals in Padang, i.e. Andalas University Teaching Hospital, Military Hospital Reksodiwiryo, and Mother and Child Hospital Siti Hawa Padang from June 2020 until the sample size fulfilled. The sample size is calculated using categorical comparative analytic research formula, $(n-1)(t-1)>15$ with $n$ as sample size and $t$ as the number of group. The sample size is then adivided into two groups, t2 which is administered with VCO and $\mathrm{t} 3$ which is not administered with VCO. From the calculation, it is obtained that the minimum sample size is 16 . To anticipate any dropout, it is added by $10 \%$ of the minimum sample size, therefore the sample size of each group is 18 women.

The sampling technique in this study is consecutive sampling, which means all women who met the inclusion criteria is included in this study until the needed number is reached. The inclusion criteria applied in this study is pregnant women who complained vaginal itching, irritation, and milky white discharge in the third trimester and willing to participate in this study by signing the informed consent after being informed well related to this study. The exclusion criteria applied in this study is pregnant women with foul smell, yellowish-green or grey-white vaginal discharge, pregnant women with vaginal bleeding, pregnant women with malignancy, pregnant women who is in medication for leucorrhea, pregnant women who refuse to participate, patient who loss to follow up, and died during the study.

The method used in this study is quasi-experimental design with pretest-posttest in the control group. This is a type of study design that aimed to know the impact of an intervention which is given purposely by the researcher. Pretest (01) was done at both groups, followed by intervention $(X)$ at intervention group. Virgin coconut oil was administered orally as determined dosage 3 times 1 tablespoon each and $5 \mathrm{cc}$ was applied at vagina using cotton every morning for 5 days for intervention group. Meanwhile control group was not given VCO. After the intervention, posttest (02) was done in the $6^{\text {th }}$ day towards both groups. The data then was collected and went through coding process to be analyzed.

Statistical analysis that was used in this study was univariate and bivariate. The data obtained from before and after the intervention then being analyzed and presented as frequency and percentage using univariate analysis. Bivariate analysis is done by using T-test. This type of test is used to compared or differentiate the mean between 2 groups. A dependent T-test is done to determine whether there was mean difference number of colonies between before and after administration of VCO for intervention group and for 


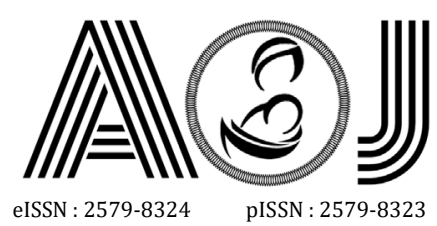

control group which was not administered with VCO. To test two means differences of two independent groups, so that it could be determined whether there was significant effect of VCO administration on intervention group and control group towards the treatment of leucorrhea caused by Candida albicans infection in pregnant women, independent T-test was used. Normality test used in this study to see the data distribution normality is Shapiro-Wilk test $(n<50)$. The data was presented as mean and standard deviation (SD). Significance of the statistic test result is determined according to $p$-value of $p<0.05$. The data obtained from this study was taken note in specific form and processed using computer software.

\section{RESULT AND DISCUSSION}

\section{Normality Test}

The normality test used in this study is Shapiro-Wilk test because the number of participants in this study was less than 50 .

Table 1. Normality test of the data

\begin{tabular}{llll}
\hline Variable & Statistic & Df & p value \\
\hline Intervention group's Pretest & 0.928 & 18 & 0.177 \\
Intervention group's Posttest & 0.975 & 18 & 0.891 \\
Control group's Pretest & 0.928 & 18 & 0.179 \\
Control group's Posttest & 0.939 & 18 & 0.284 \\
\hline
\end{tabular}

As showed in table 1, based on the result of the normality test on pretest and posttest, the number of Candida albicans colonies in the intervention group and control group was normally distributed. Therefore, the test that was used is parametric test, paired T-test and independent T-test.

\section{Mean number of colonies before and after in intervention group and control group.}

Table 2. Mean number of colonies before and after in intervention group and control group

\begin{tabular}{lllll}
\hline Variable & & $\mathbf{N}$ & Mean \pm SD & Min-Max \\
\hline Intervention group & Pretest & 18 & $\mathbf{1 3 7 . 1 7} \pm \mathbf{1 6 . 3 5}$ & $\mathbf{1 1 3 - 1 7 8}$ \\
& Posttest & & $\mathbf{1 2 2 . 1 7} \pm \mathbf{1 4 . 4 2}$ & $\mathbf{9 2 - 1 5 0}$ \\
\hline Control group & Pretest & 18 & $\mathbf{9 6 . 0 6} \pm \mathbf{8 . 8 5}$ & $\mathbf{8 2 - 1 1 0}$ \\
& Posttest & & $\mathbf{1 1 2 . 8 9} \pm \mathbf{1 2 . 4 9}$ & $\mathbf{8 7 - 1 3 1}$ \\
\hline
\end{tabular}

According to table 2, the number of Candida albicans colonies in pregnant women after the VCO administration was decreased compared to before the administration of VCO. 


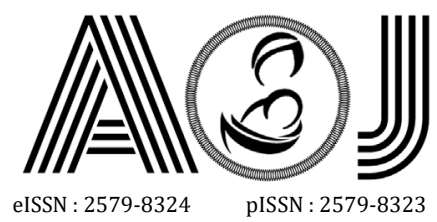

Editorial Room Andalas Obstetrics and Gynecology Journal, $3^{\text {rd }}$ floor of KSM of Obstetrics and Gynecology,

RSUP DR. M. Djamil Padang, Jl. Perintis Kemerdekaan Padang, Sumatera Barat 25127

Website:

http://jurnalobgin.fk.unand.ac.id/index.php/JOE

\section{Effect of Virgin coconut oil as the treatment of leucorrhea caused by Candida albicans on pregnant women.}

Table 3. Effect of Virgin coconut oil as the treatment of leucorrhea caused by Candida albicans on pregnant women.

\begin{tabular}{llll}
\hline Variable & N & Mean \pm SD & P value \\
\hline With VCO administration & 18 & $122.17 \pm 14.42$ & 0.047 \\
Without VCO administration & 18 & $112.89 \pm 12.49$ & \\
\hline
\end{tabular}

According to table 3, the mean number of Candida albicans colonies decreased after being administered with VCO, compared to those who were not given VCO. The statistical analysis result using independent T-test showed that the $p$-value is 0.047 or $p<0.05$. Then it could be concluded that there is effect of administration of VCO as the treatment of leucorrhea (fluor albus) caused by Candida albicans infection on pregnant women. The effect of administration of VCO could be seen from the changes in symptoms and the changes in the number of colonies before and after the intervention.

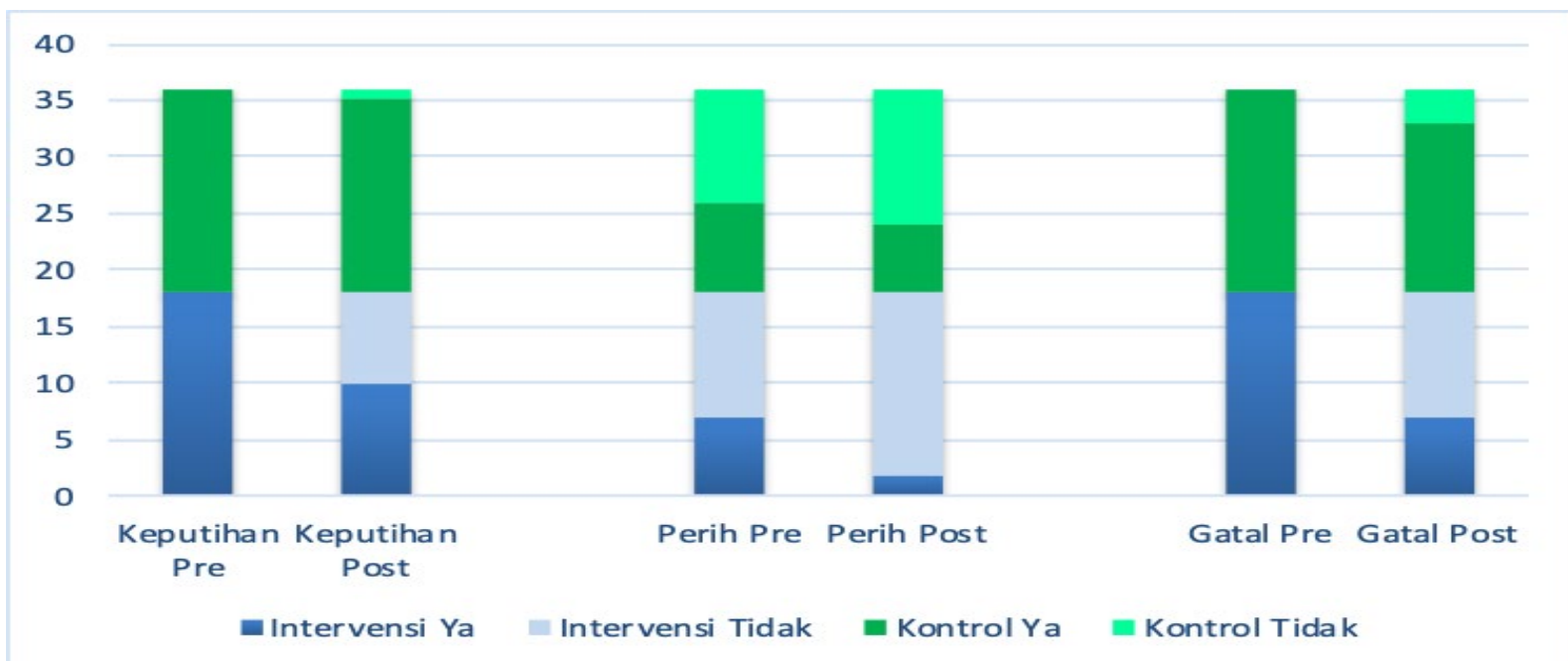

Figure 1. Clinical Symptoms Examined at Pre and Post in Intervention Group and Control Group

From Figure 1, it could be concluded there was decreasing in clinical symptoms in the intervention group. Before administration of VCO, there were 18 women who experienced leucorrhea and after administration of VCO, only 10 women who experienced leucorrhea. Meanwhile in control group, there was insignificant decreasing of clinical symptoms. In the first examination, there were 18 women who experienced leucorrhea and in the second examination there were 17 women who experienced leucorrhea. Similar result also happened in irritation complain, 7 of 18 women in intervention group complain irritation in the first examination and it remained only 2 women in the second examination. Meanwhile in control 


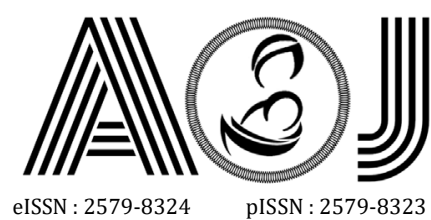

eISSN : 2579-8324
pISSN : 2579-8323

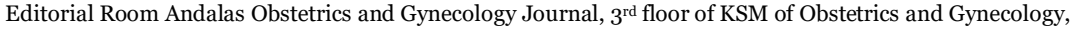

RSUP DR. M. Djamil Padang, Jl. Perintis Kemerdekaan Padang, Sumatera Barat 25127

group, 8 of 18 women who complain irritation in the first examination and 6 women complain irritation in the second examination. As well as in pruritus, all women in intervention group complain itching in the first examination and 7 women in the second examination who complain of pruritus. Meanwhile in control group, 18 women who complained of pruritus in the first examination became 13 women who complain of pruritus in the second examination.

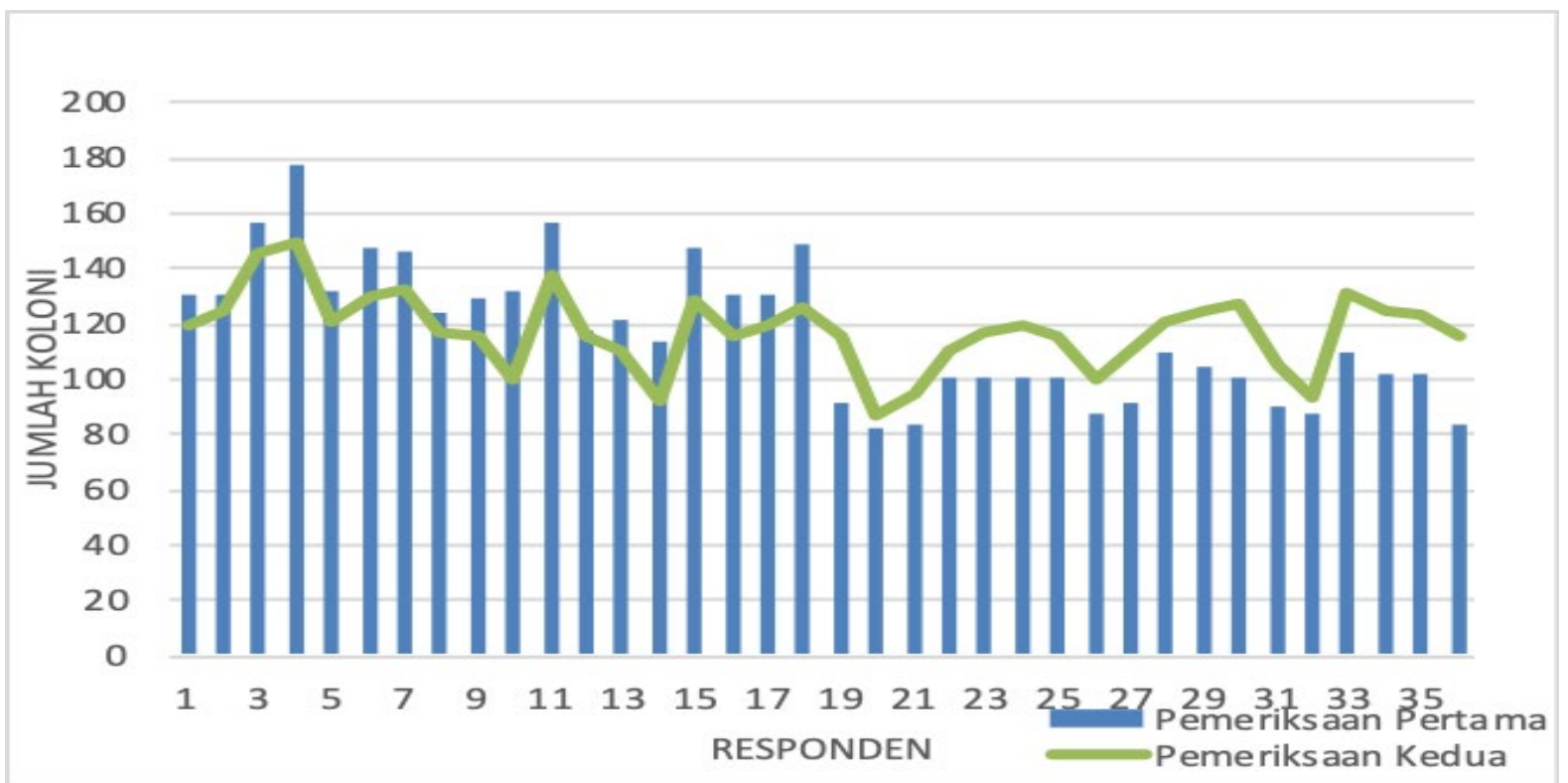

Figure 2. Changes in The Number of Colonies in Pre and Post Examination on Intervention Group and Control Group.

In the Figure 2, there were two groups, which are intervention group in the number 1 to 18 and control group in the number 19 to 36 . These groups both were examined twice. First examination is marked with blue chart and the second examination was marked with green chart. In intervention group, the green chart is inside blue chart, which means there was decreasing in the number of colonies in intervention group before and after the administration of VCO. Whereas in control group. The green chart is positioned above blue chart, which means there was increasing in the number of Candida albicans colonies.

\section{DISCUSSION}

\section{Mean Number of Colonies Before and After in Intervention Group and Control Group.}

Based on the result of this study, it was known that the administration of VCO could lowering the number of Candida albicans colonies in pregnant women. This could be seen from the result of study which is the mean number of Candida albicans colonies in intervention group in the first examination is $137.17 \pm 16.35$ colonies and in the second examination it became $122.17 \pm 14.42$ colonies. Meanwhile in the control group the mean 


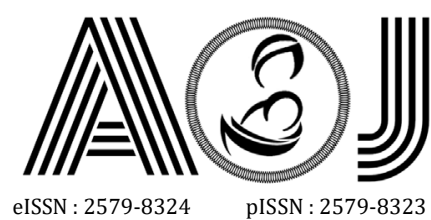

eISSN : 2579-8324
pISSN : 2579-8323

number of Candida albicans colonies was $96.06 \pm 8.85$ in the first examination and increased to $112.89 \pm 12.49$ colonies in the second examination. Consistent with the previous study conducted by Aslam, Hafeez, et al (2008), the high level of progesterone suppress effect on antifungal when neutrophil activation. ${ }^{1,4,8}$ Virgin coconut oil has an antifungal mechanism towards fatty acid by directly interacting with lipid layer on fungal cell membrane and cause a change and increasing in membrane fluidity. These increase of membrane fluidity lead to irregular cell membrane and therefore cause a change in membrane protein conformation, release of intracellular component, cytoplasm abnormality, and cell disintegration, as well as inhibition of growth in the number of Candida albicans colonies. ${ }^{20}$

According to Daili (2009), the diagnosis of Candida is done by microscopic examination, including culture with its sensitivity reach $90 \%$. It is also said that culture alone without clinical symptoms suggesting candidiasis would not determine the diagnosis of vulvovaginal candidiasis. Determining the number of Candida albicans is done using Sabouraud Dextrose Agar medium, developed by France dermatologist. This medium is helpful to support the growth of fungal colonies. The specimen should be incubated for $24-48$ hours in temperature of $37^{\circ} \mathrm{C}$. According to a study conducted by Dwidjoseputro (2005), Candida albicans colonies which grow can be counted in two methods, directly and indirectly. The direct method is done by preparing the specimen from a material (dyed) and using count space. The colonies are counted using limit switch which is placed under the petri dish. When the object is pressed, the counter will give sign to the object as the indicator buzzer make sound, so that one object would not be counted twice. ${ }^{1,4,8}$

\section{Difference in The Number of Candida albicans Colonies in Pregnant Women Between Intervention Group and Control Group with Administration of Virgin Coconut Oil}

This study showed that there was decreasing in the mean number of colonies in intervention group between the first examination and the second examination after administration of VCO. The difference in the mean number of Candida albicans colony is as much as 15 colonies and this number is also statistically significant $(p=0.000)$. Meanwhile for control group, there is increasing in the mean number of colonies between the first examination and the second examination. The difference is 16.83 colonies with $p$ value 0.000 which statistically showed the significant differences in the number of colonies between those two examinations. This decreasing in the number of colony in the second examination of control group occurred because the activity of anti-candida effect posed by VCO which cause disintegration of fungal cell plasma membrane. ${ }^{15-17}$ Unsaturated fatty acid contained in VCO is as much as $60 \%$, consist of medium-chain fatty acid which is essential for body health. The saturated fatty acid (lauric acid and capric acid) posed its antimicrobe activity so that after the administration of VCO orally or topically, it decreases the number of colonies on pregnant 


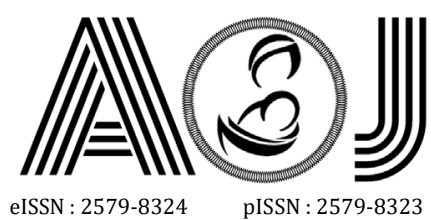

eISSN : 2579-8324
pISSN : 2579-8323

woman leucorrhea. Otherwise, there was increasing in the number of colonies in the second examination of pregnant women who was in control group and was not administered with $\mathrm{VCO}^{19}$

Consistent with the previous study conducted by Arlee (2013), three medium-chain fatty acid contained in coconut oil, one of them is capric acid $(4-8 \%)$ which function as antifungal agent. Medium-chain fatty acid contained in VCO has been proved to inhibit the growth of Chlamydia trachomatis, Helicobacter pylori, Neisseria gonorrhoe, and Candida albicans. A study about antifungal support this statement is done by Pragati R, et al (2017) which explained that combination of some antifungal agents in tissues is an alternative to delivery system of systemic or topical antifungal drug delivery. By evaluating mechanical and physical characteristics, oregano oil showed the best result among other tested groups. Besides, this material is safe and low cost so that it can be used as an alternative to synthetic agent that is recently used. ${ }^{15-17}$

\section{Effect of Administration of Virgin Coconut Oil in The Treatment of Leucorrhea Caused by Candida Albicans Infection in Pregnant Women.}

Leucorrhea in pregnant women is a clinical manifestation that would be a comorbid in pregnancy, such as premature delivery, premature rupture of membrane, placental insufficiency, and neonatal or fetal infection. Previous studies on SDA medium or in rats showed that VCO is potential to inhibit the growth of Candida. This became the basic for this study. This study showed the mean number of Candida albicans colonies decreased after administration of VCO compared to those without administration of VCO, the result is 122.17 \pm 14.42 colonies and $112.89 \pm 12.49$ ) colonies respectively. From this result, it can be concluded that there is effect of administration of VCO in the treatment of leucorrhea (fluor albus) caused by Candida albicans in pregnant women, with p value $0.047(0<0.05) .3,4,21$

Virgin coconut oil contain medium-chain fatty acid which poses antimicrobial, antifungal, and antiviral effect, including its capability to kill Candida albicans. ${ }^{22}$ Virgin coconut oil does not contain steroid which could erode Candida's cell wall which consist of polysaccharides and kitin. If a fungal cell is intact, it will stay alive and continue to grow, like those showed in control group that was not administered with VCO. There was increase in the number of colonies in the second examination of control group. Consistent with previous study conducted by Burhannudin (2017) that aimed to see the inhibition capacity of VCO toward the growth of Candida albicans in SDA medium. A 90\% concentration of VCO could inhibit the growth of candida in agar medium. Besides, VCO also contain various active substance such as monolaurin and monocaprin that could break the fungal cell membrane. ${ }^{23}$ 


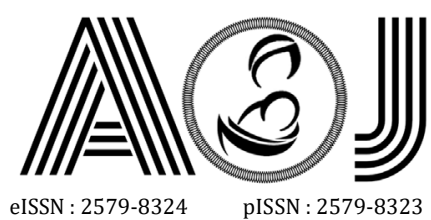

eISSN : 2579-8324
pISSN : 2579-8323

Editorial Room Andalas Obstetrics and Gynecology Journal, $3^{\text {rd }}$ floor of KSM of Obstetrics and Gynecology,

RSUP DR. M. Djamil Padang, Jl. Perintis Kemerdekaan Padang, Sumatera Barat 25127

Website:

http://jurnalobgin.fk.unand.ac.id/index.php/JOE

\section{CONCLUSION}

1. The mean number of Candida albicans colonies before and after in intervention group and control group in pregnant women is 113-178 / 92-150 for intervention group and 82-110 / 87-131 for control group in network Hospitals, Padang in 2020.

2. The differences in the number of Candida albicans colonies in pregnant women between intervention group and control group with the administration of VCO are 1 18 in intervention group and $19-36$ in control group in network Hospitals, Padang in 2020.

3. There was effect of administration of VCO on leucorrhea caused by Candida albicans infection in pregnant women $(p=0.047)$ using independent T-test as statistical analysis.

\section{REFERENCES}

1. Altayyar IA, Alsanosi AS, Osman NA. Prevalence of vaginal candidiasis among pregnant women attending different gynecological clinic at South Libya. Eur. J. Exp. Biol.. 2016;6(3):25-9.

2. Cunningham, F. G., Patel, Roberts, Zink. Williams Obstetrics.25th Infectious disease. United state. The McGraw-Hill Companies; 2019

3. Jhon F.Kennedy. Comprehensive Gynecology. 7th edition. Philadepia: library of congress cataloging- in publication. Elsivier.2017

4. Jackie S, Gilbert D DW. European (IUSTI/WHO) Guideline on the Management of Vaginal Discharge. UK: Department of Genitourinary Medicine.

5. Filippidi A, Galanakis E, Maraki S, Galanil, Drogari-Apiranthitou M, Kalmanti M, et al. The effect of maternal flora on Candida colonisation in the neonate. Mycoses. 2014;57(1):438.

6. Shiris N Daftary. Selected topics in obstetrics and gynaecology-3: For postgraudate and practitioner. 2007

7. Neville F. Hacker, Joseph C. Gambone, Calvin J. Hobel. Hacker \& Moore's Essentials of Obstetrics and Gynecology E-Book. Sydney, Australia. 2010

8. Brooks,G.F.Carrol, K.C.Butel, J. S. Dani morse. Medical microbiology. Salemba Medika. Jakarta.2004.

9. Wilkins L\&. Vaginal infection. 15th ed. India: Berek and Novak's Gynaecology

10. Walsh TJ, Hayden RT, Larone DH. Larone's medically important fungi: A guide to identification. New York, 2018

11. Malcolm D. Richardson, David W. Warnock. Fungal infection: Diagnosis and management. 2003 


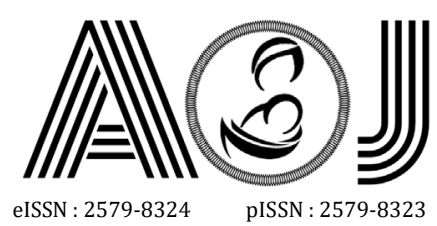

12. Mutiawati VK. Pemeriksaan mikrobiologi pada Candida Albicans. Juornal Kedokt Syiah kuala. 2016;16:53-63.

13. Aring, B. J., Mankodi, P. J., Jasani, J. H. Incidence of vaginal Candidiasis in leucorrhoea in women Attending in OPD of Gynecology and Obstetrics Department. Int J Biomed Adv Res.2012; 3(12): 867-9.

14. Soong D, Einarson A. Vaginal yeast infections during pregnancy. Can Fam Physician. 2009;55(3):255-6.

15. Syukur S. Bioteknologi virgin coconut oil dan potensi kandungan zat-zat antibodi dan antimikroba atau virus. Padang: Pusat kajian Bioteknologi Industri dan Biomolekuler Universitas Andalas Padang; 2004.

16. Widianingrum, D. C., Noviandi, C. T, Salasia SIO. Antibacterial and immunomodulator activities of virgin coconut oil (VCO) against Staphylococcus aureus. Heiyon. 2019;5.

17. Dewi SS, Aryadi T. Efektifitas virgin coconut oil ( VCO ) terhadap kandidiasis secara invitro. Pros Semin Nas Int. 2010;1(1). doi:10.1016/j.inoche.2014.10.028

18. Khan MSA et. al. Virulence and pathogenicity of fungal pathogens with special reference to Candida albicans. Berlin Heidelberg: springer-verlag Berlin Heidelberg; 2010.

19. Nasir M. M, Abllah, Z., Jalaludin A., Azura Shahdan I, Hayati Wan Abd Manan WN. Virgin coconut oil and its antimicrobial properties against pathogenic microorganisms: A review. Adv Heal Sci Res Vol 8 Int Dent Conf Sumatera Utara 2017. 2017. doi:10.2991/idcsu17.2018.51.4

20. Kett DH et. al. Candida bloodstream infections in intensive care units : Analysis of the extended prevalence of infections in intensive care unit study. Crit Care Med. 2011;39:665-670

21. Rebecca Jeanmonod; Donald Jeanmonod. Vaginal Candidiasis (Vulvovaginal Candidiasis). Last Update: April 28, 2020.

22. Poerwanto $S$, Hidayat C S. Sintesis lipida terstruktur dari asam laurat dan gliserol dalam pelarut isooktana dengan biokatalis lipase Candida rugosa. Reaktor. 2010;13(1):44

23. Tjin LD, Setiawan AS, Rachmawati E. Exposure time of virgin coconut oil against oral Candida Albicans. Padjadjaran J Dent. 2016;28(2):89-94. doi:10.24198/pjd.vol28no2.13718 